Original Article (short paper)

\title{
Tactical efficacy and offensive game processes adopted by Italian and Brazilian youth soccer players
}

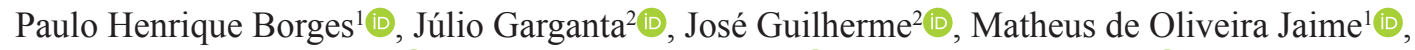 \\ Vanessa Menezes Menegassi ${ }^{1} \mathbb{D}$, Leandro Rechenchosky ${ }^{1}$, Dourivaldo Teixeira ${ }^{1} \mathbb{D}$, Wilson Rinaldi ${ }^{1}$ \\ ${ }^{1}$ Universidade Estadual de Maringa, UEM, Department of Physical Education, Maringá, \\ PR, Brazil; ${ }^{2}$ Universidade do Porto, Faculty of Sport, Porto, Portugal
}

\begin{abstract}
Aim: To analyze success and failure of offensive sequences and the adopted offensive method in under-15 (U-15) and under-17 (U-17) soccer players. Methods: The sample was composed of 218 offensive sequences performed by U-15 and U-17 players selected from 28 matches, being 18 matches of an Italian team and 10 matches of a Brazilian team. All offensive sequences which ended in finalization were selected for the analysis. Using observational methodology, an adapted ad hoc observational instrument was built with the variables "number of players involved", "ball touches", "passing", "duration", and "corridor changes". Next, offensive actions were classified into three offensive game methods: counter-attack, quick attack, and positional attack. Results: Results revealed that teams which use positional attack expend more time constructing an offensive play, involve extra players, and change the ball corridor more often during offensive actions when compared to counter-attack and quick attack $(\mathrm{p}<0.01)$. Moreover, offensive efficacy did not present an association with the offensive method employed $\left(\mathrm{X}^{2}=0.47 ; \mathrm{p}=0.78\right)$. Sequences that finished in success presented significantly higher values of the number of touches $(p=0.02)$, passes $(p=0.003)$, and duration $(p=0.01)$ in comparison to failure. Conclusion: The findings suggest that all offensive methods adopted can be used to reach success during a game of U-15 and U-17 soccer players.
\end{abstract}

Keywords: youth sports; tactical efficacy; performance indicators.

\section{Introduction}

Football is known as a team sport characterized by alternation between offensive and defensive phases of the game, where players are required to interact with their teammates to manage the constraints offered by opponents ${ }^{1}$. Given the relevance of the management of game space to achieve success, a series of studies have recently been developed, trying to understand the complex dynamics of football. Interaction between players in different situations ${ }^{2-4}$, metrics that discriminate winning, drawing and losing teams ${ }^{5,6}$, comparison between possession and direct play $^{7}$, collective dynamics evolution over the last three decades $^{8}$, and core tactical principle execution ${ }^{9-12}$ are examples of information suggested by different authors to clarify the tactical domain in football.

Regarding the offensive phase of the game, teams can basically play three offensive methods: a counter-attack, quick attack, and positional attack ${ }^{13}$. Counter-attack refers to an offensive situation with the following characteristics: i) transition from defense to attack occurs quickly in a reduced period; ii) the opposing team's defense is unbalanced; iii) actions are performed with high intensity and lower passes - especially depth passes. Quick-attack is also characterized by an intense transition from defense to attack but the opponent's defensive system is more organized than in counter-attack, and passes are performed with depth and width. The positional attack is an offensive method often used by teams with high technical and tactical qualities, where players spend more time building offensive play and collective team behavior is guided by a homogenous and compact block ${ }^{7,13-15}$.

The choice of one method over another may consider many types of information, such as the ideas of coaches, player skills, and the objectives and structure of the club, among others ${ }^{16,17}$. Furthermore, clubs need to constantly evaluate their tactical performance to understand whether the methods adopted are adjusted to the characteristics of the team ${ }^{7}$. Match analysis has been used for this purpose through observational methodology ${ }^{18-22}$.

Although the number of studies related to observational analysis in football has increased over the last few years, it remains unclear whether the offensive methods and behaviors adopted are related to offensive efficiency. Tenga, Ronglan L, $\mathrm{Bahr}^{23}$ reported that offensive sequences with fewer passes increase the chances of producing opportunities for scoring goals compared to elaborate attacks. In contrast, Lago-Peñas, Lago-Ballesteros and $\mathrm{Rey}^{24}$ found that winning teams had significantly higher average values of passes and ball possession than loser teams. Besides these controversial findings, the majority of studies published in the literature were conducted with adult football players and not youth footballers ${ }^{7,25}$. Therefore, new studies investigating offensive sequences in youth players 
may reveal which offensive method is more efficient at these ages. This information might help coaches to identify patterns and indicators that could be used as references during training ${ }^{26}$.

Thus, the aim of this study is to analyze the success and failure of offensive sequences and the adopted offensive method in U-15 and U-17 soccer players.

\section{Methods}

\section{Participants}

This is an observational study, with an extensive-point-idiographic-unidimensional design. According to Anguera ${ }^{27}$ and Portell, Anguera, Chacón-Moscoso, Chaves ${ }^{28}$, the observational methodology allows monitoring the behaviour in the context where it happens, prioritizing contextual representativeness of the data with quality in a context without standardized evaluation tools. The present study shows a single level of response expressed by a unidimensional design, with a group of users, in a specific moment of observation, focusing on static behavioural indicators.

The sample consisted of 218 offensive actions selected from 28 matches, including 18 matches of the Italian team U-15 in dispute for the Italian championship, season 2015/2016, and 10 matches of the Brazilian team - 5 matches U-15 and 5 matches U-17 - in dispute for the national and state championship, season 2016. Matches were randomly selected along the season. The Brazilian and Italian teams were selected as they represent traditional soccer-playing countries, which usually produce good young players. The Brazilian club included athletes selected from many states of the country and a weekly routine composed of five training sessions, whereas the Italian club presented a weekly routine composed of three training sessions, and generally included players selected from nearby towns.

The clubs were duly informed about the procedures to be adopted and signed the free and informed consent term. The study was included in the institutional research project titled "Tactical behavior in football: Evaluation of offensive tactical actions and their implications in the process of sports training of young soccer players", approved by the Ethics Committee of the State University of Maringá (Proc. 1.627.516).

The following inclusion criteria were adopted: (1) Offensive sequences that finished in shooting towards opponent's goal; (2) Free and informed consent term signed by the responsible clubs, and as exclusion criteria: (1) Free kick with direct shooting towards the opponent's goal; (2) Offensive sequences that did not present the criteria for characterizing the offensive methods proposed by Garganta ${ }^{29}$.

\section{Procedures}

To obtain the videos, the cameras were located on a high plane in relation to the game plan to facilitate a topographic view of the playing field. Data collection was performed through observational analysis using Match Vision Studio Premium ${ }^{\circledR}$ software ${ }^{30-32}$. This software enables the researcher to create a categorical matrix according to the variables to be analyzed (Figure 1).

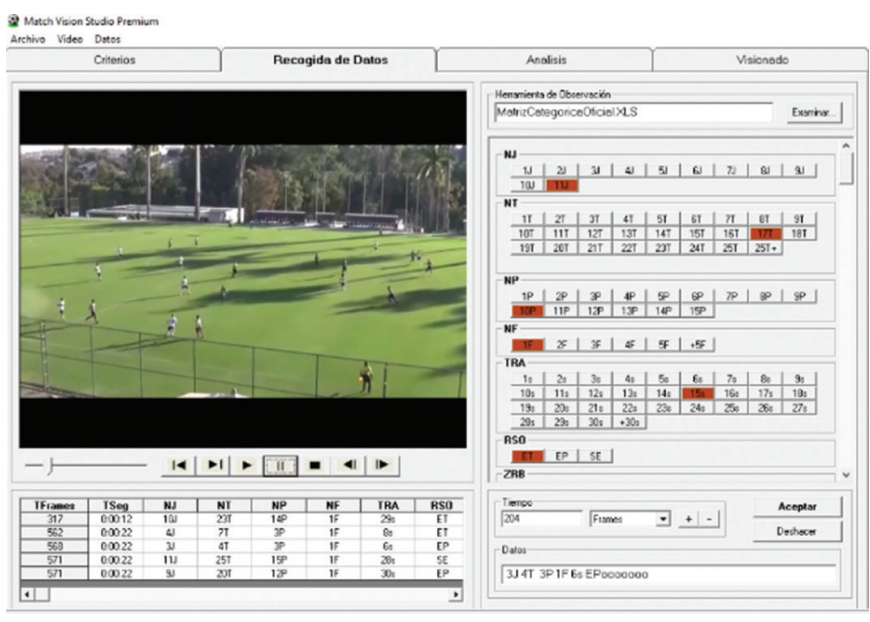

Figure 1. Screen capture from Match Vision Studio Premium ${ }^{\circledR}$ software with the categorical matrix used in the study.

Only the offensive actions which ended in finalization were selected, as suggested by Almeida ${ }^{33}$. The variables used to create the categorical matrix were proposed by Garganta ${ }^{29}$ and Almeida ${ }^{33}$, and are presented in Table 1.

Table 1. Categories of offensive actions and results of the offensive actions.

\begin{tabular}{ll}
\hline \multicolumn{1}{c}{ Variables } & \multicolumn{1}{c}{ Description } \\
Players Involved & $\begin{array}{l}\text { Number of players that were involved, } \\
\text { touching the ball during the offensive action. } \\
\text { Total number of ball touches performed by } \\
\text { players during the offensive action. } \\
\text { Total number of passes made with any part of } \\
\text { the body that was received by the attacking } \\
\text { partner and continued the offensive phase of } \\
\text { the team. } \\
\text { Passing }\end{array}$ \\
$\begin{array}{ll}\text { The duration of the offensive phase, from } \\
\text { the interception of the ball, to the end of the } \\
\text { offensive action (seconds). }\end{array}$ \\
Duration & $\begin{array}{l}\text { Number of times that the ball changed field } \\
\text { corridors during the offensive action, taking } \\
\text { into account the division of the field into } 3 \\
\text { corridors (left, central, and right). }\end{array}$ \\
Corridor & \multicolumn{1}{c}{ Description } \\
Changes* & $\begin{array}{l}\text { Sequence finished in goal. } \\
\text { Sequence finished with kick out or } \\
\text { goalkeeper's defense. }\end{array}$ \\
\hline Success & Failure
\end{tabular}

*Spatial references for corridor changes can be found in Gréhaigne, Mahut and Fernandez ${ }^{34}$.

All sequences where players scored a goal were considered as successful sequences, and those sequences which finished 
with kick out or goalkeeper's defense were classified as a failure. The characterization of the offensive game method proposed by Garganta ${ }^{29}$, and presented in Table 2 was used to identify the different playing styles during the offensive actions: counter-attack (CA), quick attack (QA), and positional attack (PA).

Table 2. Characteristics of Offensive Game Methods.

\begin{tabular}{lll}
\hline \multicolumn{1}{c}{$\begin{array}{c}\text { Counter } \\
\text { attack (CA) }\end{array}$} & Quick attack (QA) & \multicolumn{1}{c}{$\begin{array}{c}\text { Positional } \\
\text { attack (PA) }\end{array}$} \\
\hline $\begin{array}{l}\text { Ball recovered in any } \\
\text { area of the playing } \\
\text { field }\end{array}$ & $\begin{array}{l}\text { Ball recovered in } \\
\text { any area of the } \\
\text { playing field }\end{array}$ & $\begin{array}{l}\text { Ball recovered in } \\
\text { any area of the } \\
\text { playing field }\end{array}$ \\
\hline $\begin{array}{l}\text { Performs equal or } \\
\text { less than 5 passes }\end{array}$ & $\begin{array}{l}\text { Performs a } \\
\text { maximum of 7 } \\
\text { passes }\end{array}$ & $\begin{array}{l}\text { Performs more than } \\
7 \text { passes }\end{array}$ \\
\hline $\begin{array}{l}\text { Offensive sequence } \\
\text { duration equal to or } \\
\text { less than 12 seconds }\end{array}$ & $\begin{array}{l}\text { Offensive sequence } \\
\text { duration equal to or } \\
\text { less than 18 seconds }\end{array}$ & $\begin{array}{l}\text { Offensive sequence } \\
\text { duration exceeding } \\
18 \text { seconds }\end{array}$ \\
\hline $\begin{array}{l}\text { Opponent team } \\
\text { advanced on the } \\
\text { pitch and defensively } \\
\text { unbalanced }\end{array}$ & $\begin{array}{l}\text { Opponent team } \\
\text { balanced defensively }\end{array}$ & $\begin{array}{l}\text { Opponent team } \\
\text { balanced defensively }\end{array}$ \\
\hline $\begin{array}{l}\text { Ball circulation more } \\
\text { in depth than width }\end{array}$ & $\begin{array}{l}\text { Ball circulation in } \\
\text { width and depth }\end{array}$ & $\begin{array}{l}\text { Ball circulation more } \\
\text { in width than depth }\end{array}$ \\
\hline $\begin{array}{l}\text { High play intensity } \\
\text { High play intensity }\end{array}$ & $\begin{array}{l}\text { Cadenced play } \\
\text { intensity }\end{array}$ \\
\hline
\end{tabular}

\section{Quality control of data}

Regarding data control, 42 offensive sequences were randomly selected to be analysed by an independent evaluator and reanalysed by the main evaluator, aiming to get the agreement between intra and inter rates. In this sense, The Kappa index was applied for qualitative variables of the study and intraclass correlation coefficient for quantitative variables, according to recommendations exposed in the literature ${ }^{35}$. All variables presented $\mathrm{k}>0.81$ and $\mathrm{r}>.91$, indicating a reliability "near perfect" ${ }^{\prime 3}$.

\section{Statistical analysis}

Non-parametric analysis was employed and data are presented as median, and first and third quartiles (Q1-Q3). To compare offensive methods and tactical-technical variables, the Kruskal-Wallis and Mann Whitney U tests were adopted. Afterward, Eta Squared test $\left(\eta^{2}\right)$ was used to verify effect size. The Chi-Squared test through the Pearson method was employed to verify the association between the offensive method and sequence outcome $(\mathrm{p}<0.05)$.

To verify the level of relationship between variables, Correlation Network Analysis was executed among tactical-technical variables in offensive sequences that finished in success. The variables "players involved", "ball touches", "passing", "duration", and "corridor changes" were analyzed and correlated using the Spearman method. Each node represents a variable and the edges that connect the nodes represent the correlation value. The thickness of the edges and colors are related to the correlation strength (as shown in figure 3 ). Only correlations equal to or above $\mathrm{r}=0.3$ were inserted in the analysis. Social Network Analysis (SNA) has been used to investigate individual and collective behavior in team sports ${ }^{37}$.

The programs Statistical Package for the Social Sciences - SPSS (v. 22.0), R (v. 3.5.1) and RStudio (v. 1.1.456) were used. The "R" packages adopted were "tidyverse", "corrr", "igraph", and "ggraph".

\section{Results}

Table 3 presents the comparisons of tactical-technical indicators among the offensive methods evaluated: counter-attack, quick attack, and positional attack. The results showed that positional attack differed significantly from the other sequences $(\mathrm{p}<0.01)$, is structured with a higher number of "players involved", "passes", "ball touches", and "ball corridor changes". In addition, positional attack sequences presented longer duration, considering the time of execution in seconds.

Table 3. Comparison of tactical-technical indicators between different offensive methods.

\begin{tabular}{|c|c|c|c|c|c|}
\hline & Counter-Attack & Quick Attack & Positional Attack & \multirow{2}{*}{$\mathbf{p}$} & \multirow{2}{*}{$\eta^{2}$} \\
\hline & Md (Q1-Q3) & Md (Q1-Q3) & Md (Q1-Q3) & & \\
\hline Players Involved (no) & $3.00(2.00-3.00)$ & $3.00(2.00-4.00)$ & $8.00(7.00-9.00)^{*}$ & $<0.01$ & 0.23 \\
\hline Passing (no) & $2.00(2.00-3.00)$ & $2.00(1.00-3.00)$ & $9.50(8.00-11.25)^{*}$ & $<0.01$ & 0.24 \\
\hline Duration (sec.) & $11.00(9.00-12.00)$ & $8.00(4.50-14.00)$ & $30.00(26.00-36.25)^{*}$ & $<0.01$ & 0.25 \\
\hline Ball Touches (no) & $7.00(5.00-8.00)$ & $6.00(3.00-9.00)$ & $24.00(20.00-25.50)^{*}$ & $<0.01$ & 0.24 \\
\hline Corridor Changes (no) & $1.00(0.00-2.00)$ & $1.00(1.00-2.00)$ & $5.00(3.00-7.00)^{*}$ & $<0.01$ & 0.17 \\
\hline
\end{tabular}

*Different from Counter-Attack and Quick Attack

Table 4 presents the association between offensive methods according to the sequences that ended in success (goal) or failure. The findings show that the three methods were similarly efficient when considering the achievement of success in the offensive sequence. However, quick attack sequences were more frequently adopted by teams when trying to progress offensively. 
Table 4. Association between different offensive methods and sequence outcome.

\begin{tabular}{lcccc}
\hline & $\begin{array}{c}\text { Success } \\
(\mathbf{n = 3 7 )}\end{array}$ & $\begin{array}{c}\text { Failure } \\
(\mathbf{n}=\mathbf{1 8 1})\end{array}$ & \multirow{2}{*}{$\mathbf{X}^{\mathbf{2}}$} & $\mathbf{p}$ \\
\cline { 2 - 3 } & $\boldsymbol{f ( \% )}$ & $\boldsymbol{f ( \% )}$ & & \\
\hline Counter-Attack $(\mathrm{n}=27)$ & $5(18.5)$ & $22(81.5)$ & & \\
Quick Attack $(\mathrm{n}=173)$ & $28(16.2)$ & $145(83.8)$ & 0.47 & 0.78 \\
Positional Attack $(\mathrm{n}=18)$ & $4(22.2)$ & $14(77.8)$ & & \\
\hline
\end{tabular}

Figure 2 shows the comparisons of tactical-technical indicators according to sequence outcome efficiency (success or failure). The results demonstrate that the number of players involved and ball corridor changes was similar in both situations $(\mathrm{p}>0.05)$. Sequences that ended in success presented significantly higher values of "number of touches" $(p=0.02)$, "passes" $(p=0.03)$, and "duration" ( $p=0.01)$ in comparison to failure.

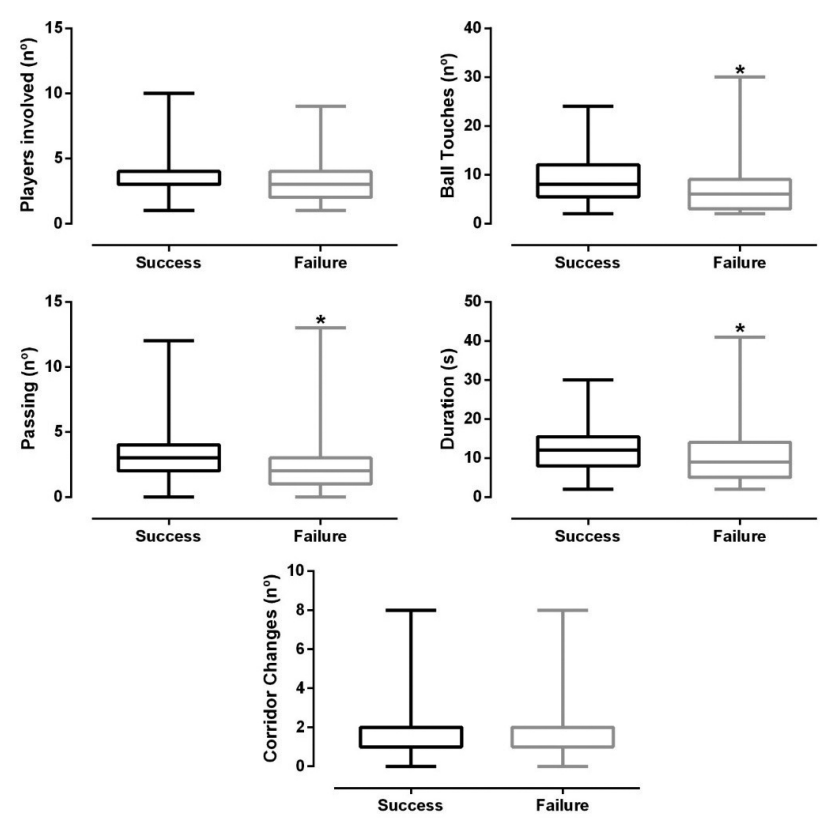

Figure 2. Comparison of tactical-technical indicators according to sequence outcome.

With regard to Figure 3, correlation network analysis among tactical and technical variables executed in offensive sequences that finished in success presented an important centrality of the variables "passing", "ball touches", and "duration".

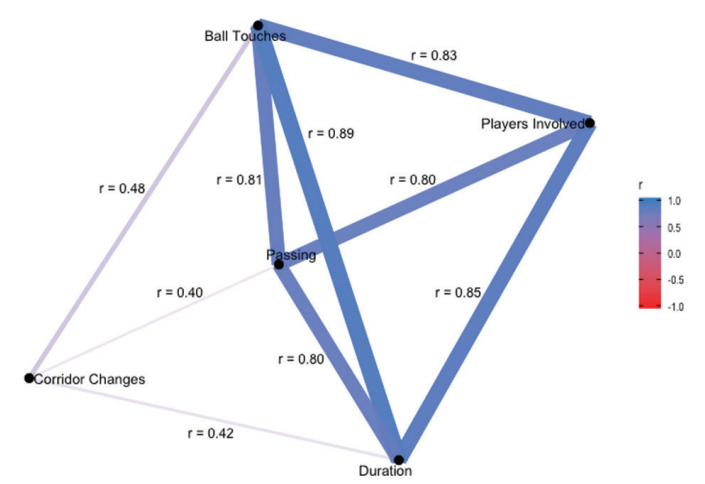

Figure 3. Correlation network analysis among tactical and technical variables in offensive sequences that finished in success (goal).
This means that in offensive sequences, these variables are central components to achieve the goal, as well as which, these variables are related to each other and presented strong correlations with the other tactical-technical indicators.

\section{Discussion}

The study aimed to analyze success and failure of offensive sequences and the adopted offensive method in U-15 and U-17 soccer players. The findings showed that there was no greater efficiency in achieving success in the offensive sequence, according to the method adopted (Table 2). These indications corroborate with several studies ${ }^{38-41}$ which report that different styles of offensive construction can be equally effective as long as they are well executed and disciplined. Top-performing teams are able to impose and maintain their game standard, regardless of their opponent, the location of the game, or possible situational changes throughout the game ${ }^{42}$.

In relation to the contributions of the tactical-technical characteristics of the adopted offensive method (Table 3), it was found that the construction positional attack showed a significant difference in corridor changes $(p<0.01)$, ball touches $(p<0.01)$, passes $(p<0.01)$, duration $(p<0.01)$, and players involved $(\mathrm{p}<0.01)$ when compared to the other methods adopted. It is believed that teams that seek an offensive construction with the positional attack are technically superior ${ }^{42}$, preferring to control the game, dictating the rhythm instead of giving the initiative to the opponent ${ }^{40}$, thus being more conservative, with a greater tendency to maintain ball possession, practicing an indirect game. Some studies indicated that these behaviours could help teams to win the game $\mathrm{g}^{43,44}$.

On the other hand, two explanations may help to explain why counter-attack and quick attack presented less "players involved", "passing", "duration", "ball touches", and "corridor changes" than positional attack (Table 3). Firstly, both methods are characterized by a fast transition from defense to attack, where teams make deep passes to reach the opposing goal quickly. Given the risks associated with sending the ball to areas that are occupied mainly by opposing teams, the loss of ball possession is often observed. Secondly, even when playing with high rhythm and fast offensive transitions ${ }^{7}$, teams organize their offensive phase of the game with a low quantity of passes and players involved.

To control the match while maintaining ball possession may be an important strategy to prevent the team from being attacked, as it maintains the balance of the team, with advanced positioning on the field, facilitating ball possession recovery in the most offensive half of the field. The place where the ball is recovered may be a preponderant factor to obtain success ${ }^{27}$, since constructions with characteristics of fast attack usually occur after recovering ball possession in the offensive field which generates shots on goal ${ }^{41}$, while also leaving the opposing defensive system unorganized. In the present study, we found a higher frequency of finishing with fast attack characteristics (Table 4). 
Other studies indicate that offensive sequences constructed with counter-attack characteristics are more effective than elaborate sequences ${ }^{23,45,46}$. However, the effectiveness of counter-attack actions is strictly related to the capabilities and organization of the opposing team; counter-attacks are more effective than other methods when the opponent presents an unbalanced and unorganized defense $\mathrm{e}^{23,45,46}$.

Regarding the contributions in Figure 2, the study identified that all the successful offensive sequences differed significantly in "touches" $(p=0.02)$, "passes" $(p<0.01)$, and "duration" $(p=0.01)$ compared to failure. In addition, the correlation network analysis in Figure 3 also presented the importance of these three variables ("ball touches", "passes", and "duration") in offensive sequences that finished in success (goal), showing that they are related to each other and presented moderate to strong $(r>0.30)$ correlations with the other tactical-technical indicators. These results reinforce the indications of Liu, Gomez, Gonçalves, Sampaio ${ }^{47}$ and Kite and Nevill ${ }^{48}$ who infer that successful teams make more ball touches and more passes in a shorter time during offensive sequences, indicating the greater success of the actions with high speed of ball transmission. Moreover, failure actions are interrupted before their conclusion, while successful sequences are those where players develop their tactical and technical intentions.

According to Garganta, Guilherme, Barreira, Brito, Rebelo $^{49}$, in order to achieve effectiveness the fundamental objective in the transition from the defensive moment to the offensive moment, must be to progress towards the adversary crossings, in a fast and effective way, taking advantage of the opponent's momentary positional disorganization, although in many cases greater efficiency is achieved when the players opt for paths that, although theoretically more time-consuming, are more accessible as they do not present so many obstacles. This behavior should be encouraged from the initial categories, as it prevents the player from losing sight of the main objective of the game (goal), seeking to prevent an exacerbated indirect game $^{50}$.

As a possible limitation of the study, we consider the use of only two national teams from two countries, by this way, limiting the possibilities of assuming similar results for other contexts. However, the results proved relevant to better fill the existing gap in relation to studies on the success, failure, and offensive methods used in actions performed by young players, $\mathrm{U}-15$ and $\mathrm{U}-17$.

\section{Conclusion}

In conclusion, we identified that all offensive methods may be used to reach success during a game of U-15 and U-17 soccer players. Therefore, coaches involved with training youth players should consider that there is not only one way to manage offensive movements during a game. All the offensive methods adopted can provide efficient outcomes. It is possible that player characteristics, the ideas of coaches, game model, training methods, and cultural aspects are factors that affect game performance.

\section{References}

1. Barreira D, Garganta J, Guimarães P, Machado J, Anguera MT. Ball recovery patterns as a performance indicator in elite soccer. J Sports Engineering and Technology. 2014; 228(1): 61-72.

2. Grund TU. Network structure and team performance: The case of English Premier League soccer teams. Soc Networks. 2012; 34(4): 682-690.

3. Clemente F, Martins F. Estudo da sequência de passes entre jogadores profissionais de futebol durante os jogos em casa ao longo de uma época desportiva: aplicabilidade das medidas de social network analysis. Revista iberoamericana de psicologia del ejercicio y el deporte. 2017; 12(2): 195-202.

4. Praça GM, Clemente F, Andrade AG, Morales JC, Greco PJ. Network analysis in small-sided and conditioned soccer games: the influence of additional players and playing position. Kinesiology. 2017; 49(2): 185-193.

5. Carvalho FM, Scaglia AJ, Teoldo I. Influence of tactical performance over the final score of small-sided soccer matches. J Phys Educ. 2013; 24(3): 393-400.

6. Winter $\mathrm{C}$, Pfeiffer M. Tactical metrics that discriminate winning, drawing and losing teams in UEFA Euro $2012^{\circledR}$. J Sport Sci. 2015; 34(6): 1-7.

7. Kempe M, Vogelbein M, Memmert D, Nopp S. Possession vs. Direct Play: Evaluating Tactical Behavior in Elite Soccer. Int J Sports Science. 2014; 4(6): 35-41.

8. Barreira D, Garganta J, Castellano J, Machado J, Anguera MT. How elite-level soccer dynamics has evolved over the last three decades? Input from generalizability theory. Cuadernos de Psicología del Deporte. 2015; 15(1): 51-62.

9. Castelão D, Garganta J, Santos R, Teoldo I. Comparison of tactical behaviour and performance of youth soccer players in 3v3 and 5v5 small-sided games. Int J Perf Anal Spor. 2014; 14(3): 801-813.

10. Gonzaga AS, Albuquerque MR, Malloy-Diniz LF, Greco JP, Teoldo I. Affective decision-making and tactical behavior of under-15 soccer players. PlosOne. 2014; 9(6): e101231.

11. Silva RN, Teoldo I, Garganta J, Muller ES, Castelão DP, Santos J. Desempenho tático de jovens jogadores de futebol: comparação entre equipes vencedoras e perdedoras em jogo reduzido. R Bras Ci e Mov. 2013; 21(1): 75-90.

12. Rechenchosky L, Borges PH, Menegassi VM, Jaime MO, Guilherme J, Teoldo I, Rinaldi W. Comparison of tactical principles efficiency among soccer players from different game positions. Hum Mov. 2017; 18(5): 31-38.

13. Castelo J. Futebol - Organização Dinâmica do Jogo. Lisboa, Edições FMH, 2004.

14. Soroka A, Bergier J. Actions with the ball that determine the effectiveness of play in women's football. J Hum Kinet. 2010; 26(1): 97-104.

15. Hewitt A, Greenham G, Norton K. Game style in soccer: what is it and can we quantify it? Int J Perf Anal Spor. 2016; 16(1): 355-372.

16. Maciel J. Não o deixes matar: o bom futebol e quem o joga. Lisboa, Chiado Editora, 2011.

17. Casarin RV, Silva RR, Greboggy D, Afonso CA, Scaglia AJ. Modelo de jogo e processo de ensino no futebol: princípios globais e específicos. Movimento. 2011; 17(3): 133-152. 
18. Fernandez J, Camerino O, Anguera MT, Jonsson G. Identifying and analyzing the construction and effectiveness of offensive plays in basketball by using systematic observation. Behav Res Methods. 2009; 41(3): 719-730.

19. Sarmento H, Leitao J, Anguera MT, Campaniço J. Observational methodology in football: Development of an instrument to study the offensive game in football. Motricidade. 2009; 5(3): 19-24.

20. Lapresa D, Álvarez L, Arana J, Garzón B, Caballero V. Observational analysis of the offensive sequences that ended in a shot by the winning team of the 2010 UEFA Futsal Championship. J Sport Sci. 2013; 31(15): 1731-1739.

21. Machado JC, Barreira D, Garganta J. Eficácia ofensiva e variabilidade de padrões de jogo em futebol. Rev Bras Educ Fís Esporte. 2013; 27(4): 667-677.

22. Anguera MT, Camerino O, Castañer M, Sánchez-Algarra $P$, Onwuegbuzie A. The Specificity of Observational Studies in Physical Activity and Sports Sciences: Moving Forward in Mixed Methods Research and Proposals for Achieving Quantitative and Qualitative Symmetry. Front psychol. 2017; 19(8): 1-14.

23. Tenga A, Ronglan L, Bahr R. Measuring the effectiveness of offensive match-play in professional soccer. Eur J Sport Sci. 2010; 10(4): 269-277.

24. Lago-Peñas C, Lago-Ballesteros J, Rey E. Differences in performance indicators between winning and losing teams in the UEFA Champions League. J Hum Kinet. 2011; 27(1): 135-146.

25. Lago-Peñas $C$, Martin R. Determinants of possession of the ball in soccer. J Sport Sci. 2007; 25(9): 969-974.

26. Garganta J, Maia J, Basto F. Analysis of Goal-Scoring Patterns in European Top Level Soccer Teams. In: Science and Football III. London; 1997, p. 246-250.

27. Anguera MT, Hernández-Mendo A. Metodología observacional y psicologia del deporte: estado de la cuestión. Rev Psicol Deporte. 2014; 23(1): 103-109.

28. Portell M, Anguera MT, Chacón-Moscoso S, Chaves SS. Guidelines for reporting evaluations based on observational methodology. Psicothema. 2015; 27(3): 283-289.

29. Garganta, J. Modelação táctica do jogo de futebol: estudo da organização da fase ofensiva em equipas de alto rendimento. Porto. Tese [Doutorado em Ciências do Desporto] - Universidade do Porto; 1997.

30. Castellano J, Perea A, Alday L, Hernández-Mendo A. The measuring and observation tool in sports. Behav Res Methods. 2008; 40(3): 898-905.

31. Camerino O, Chaverri J, Anguera MT, Jonsson G. Dynamics of the game in soccer: Detection of T-patterns. Eur J Sport Sci. 2012; 12(3): 216-224.

32. Almeida CH, Duarte R, Volossovitch A, Ferreira AP. Scoring mode and age-related effects on youth soccer team's defensive performance during small-sided games. J Sport Sci. 2016; 34(14): 1355-1362.

33. Almeida C. Caracterização das sequências ofensivas no futebol juvenil: Efeitos da experiência e de variantes reduzidas do jogo. Lisboa. Dissertação [Treino do jovem atleta] - Universidade Técnica de Lisboa; 2010.

34. Gréhaigne JF, Mahut B, Fernandez A. Qualitative observation tools to analyse soccer. Int J Perf Anal Sport. 2001; 1(1): 52-61.
35. Barros MVG, Reis RS, Hallal PC, Florindo AA, Junior JCF. Análise de dados em saúde. Londrina: Midiograf, 2012.

36. Maroco J. Análise estatística com o SPSS Statistics. Lisboa: ReportNumber, 2014.

37. Lusher D, Robins G, Kremer P. The Application of Social Network Analysis to Team Sports. Measurement in Physical Education and Exercise Science. 2010; 14(4): 211-224.

38. Hughes M, Franks I. Analysis of passing sequences, shots and goals in soccer. J Sport Sci. 2005; 23(5): 509-514.

39. Lago-Peñas C. The influence of match location, quality of opposition, and match status on possession strategies in professional association football. J Sport Sci. 2009; 27(13): 1463-1469.

40. Collet $\mathrm{C}$. The possession game? A comparative analysis of ball retention and team success in European and international football, 2007-2010. J Sport Sci. 2013; 31(2): 123-136.

41. Vogelbein M, Nopp S, Hökelmann A. Defensive transition in soccer - are prompt possession regains a measure of success? A quantitative analysis of German Fußball-Bundesliga 2010/2011. J Sport Sci. 2014; 32(11): 1076-1083.

42. Lago-Peñas C, Gómez-Ruano M, Yang, G. Styles of play in professional soccer: an approach of the Chinese Soccer Super League. Int J Perf Anal Spor. 2018; 17(6): 1073-1084.

43. Lago-Peñas C, Lago-Ballesteros J, Dellal A, Gomes M. Gamerelated statistics that discriminated winning, drawing and losing teams from the Spanish soccer league. J Sports Sci. 2010; 9(2): 288-293.

44. Liu H, Gomez MA, Lago-Peñas C, Sampaio J. Match statistics related to winning in the group of 2014 Brazil FIFA World Cup. J Sports Sci. 2015; 33(12): 1205-1213.

45. Lago-Ballesteros J, Lago-Peñas C, Rey E. The effect of playing tactics and situational variables on achieving score-box possessions in a professional soccer team. J Sport Sci. 2012; 30(14): 1455-1461.

46. Gonzales-Rodenas J, Lopez-Bondia I, Calabuig F, James N, Aranda R. Association between playing tactics and creating scoring opportunities in elite football: A case study in Spanish Football National Team. J Hum Sport Exercise. 2015; 10(1): 65-80.

47. Liu H, Gomez M, Gonçalves B, Sampaio J. Technical performance and match-to-match variation in elite football teams. J Sport Sci. 2016; 34(6): 509-518.

48. Kite C, Nevill A. The Predictors and Determinants of InterSeasonal Success in a Professional Soccer Team. J Hum Kinet. 2017; 58(1): 157-167.

49. Garganta J, Guilherme J, Barreira D, Brito J, Rebelo A. Fundamentos e Praticas para o Ensino e Treino do Futebol. In: Jogos Desportivos Coletivos: Ensinar a jogar. Porto, Faculdade de Desporto da Universidade do Porto; 2013. p. 199-263.

50. Garganta J. Competências no ensino e treino de jovens futebolistas. EF Deportes. 2002; 8(45): 1-6.

\section{Acknowledgements}

We would like to thank the Coritiba Football Club and Associazione Calcio Pisa for permission to perform this study with their youth soccer 
players. We are also grateful to the Coordination of Improvement of Higher Education Personnel (CAPES/Brazil) for the Master Scholarship conceded to M.O.J and V.M.M.

\section{Corresponding author}

Paulo Henrique Borges

Department of Physical Education, State University of Maringá. Colombo Avenue, 5790, Block M06, Room 18. Postal Code: 87020-900, Maringá, Paraná, Brazil.

Email: pauloborges.uem@gmail.com
Manuscript received on November 18, 2018

Manuscript accepted on March 17, 2019

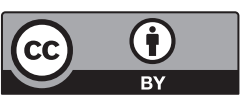

Motriz. The Journal of Physical Education. UNESP. Rio Claro, SP, Brazil - eISSN: 1980-6574 - under a license Creative Commons - Version 4.0 